\title{
Zinc Finger MYM-Type Protein 2
}

National Cancer Institute

\section{Source}

National Cancer Institute. Zinc Finger MYM-Type Protein 2. NCI Thesaurus. Code C97875.

Zinc finger MYM-type protein 2 (1377 aa, $155 \mathrm{kDa}$ ) is encoded by the human ZMYM2 gene. This protein plays a role in the modulation of transcription. 